\title{
The Problems in Learning of Chookai
}

\author{
Soni Mulyawan Setiana \\ Japanese Department \\ Universitas Komputer Indonesia \\ Bandung, Indonesia \\ soni.mulyawan@email.unikom.ac.id
}

\author{
Anisa Arianingsih \\ Japanese Department \\ Universitas Komputer Indonesia \\ Bandung, Indonesia \\ anisa@email.unikom.ac.id
}

\begin{abstract}
This study was aimed to describe the problems faced by students in learning Chookai and how the efforts of lecturer to overcome the problems. The research design was action research. The data were taken through questionnaire to the students and documentation studies. The Respondents in this study are 32 students of 2nd grade of Japanese Department at Universitas Komputer Indonesia. The results of this study illustrates that more than half of the respondents, namely $\mathbf{5 9 . 4 \%}$ stated that chookai is a difficult subject, as for the problems faced, namely the difficulty of students in understanding vocabulary, sentence patterns, short conversation content, and long conversation content in Japanese. The causative factors are divided into two, namely internal factors and external factors. Efforts made by students to overcome these difficulties are: asking friends or lecturers when experiencing difficulties; often listening to songs, watching films or doramas, and reading comics in Japanese; Often communicate using Japanese with friends, lecturers and Japanese people to improve listening skills, as well as; more active and earnest in learning, both independently and in groups. Considering the importance of listening skills, teachers should provide better motivation to students to study hard to improve listening skills.
\end{abstract}

Keywords-Problems, Learning, Chookai

\section{INTRODUCTION}

Listening or in Japanese called chookai is one of the elements of four language skills that have an important role in mastering the language that functions to receive information orally. Sudjianto explained that chookai is to receive information verbally from speaking activities [1]. Cameron explained that listening skills are one of the most important components in human life to communicate. This is because people spend more than 45 percent of their communication time listening, which is more than other communicative activities [2]. As a skill, listening is a skill that all learners must have in order to understand the language spoken by others verbally. Listening skills are an important part and cannot be ignored in language teaching to achieve good mastery of language skills. Tarigan explains that without good listening skills, it is possible to have misunderstandings in communication between fellow language users which can cause various obstacles in daily activities [3]. Furthermore, Wallace argues that listening ability is a very important skill because through this listening skill that makes humans gain knowledge, understanding, knowledge, and information, and achieve success in communicating with others. [4].

In its implementation, Yagang explained that some teachers think that listening is the easiest skill to teach, while most students think it is the most difficult to improve [5]. Furthermore, Shi explained that in learning English, $43.2 \%$ of students thought that listening comprehension was the most difficult thing. This has become one of the obstacles for students in learning English. Therefore students have difficulty developing their English language skills. [6]. Miller argued that one of the factors that caused students' difficulties in listening was the assumption that listening skills were not very important compared to speaking, writing and reading skills. [7] Furthermore, Yagang explained that the cause of listening was difficult because it came from four sources, including: the message to be listened to, the speaker, the listener, and the physical setting [5]. The other causes of difficulty are explained by Wagner and Toth, that is, foreign language texts in textbooks that students say are mostly not authentic [8]. Bingol describes that the problems which become obstacles for students in listening, include quality of recorded material, cultural differences, accent,unfamiliar vocabulary, length and speed of the listening, lack of concentration and physical conditions [9].

Empirical experience proves that for foreign learners who learn Japanese in Indonesia, listening or chookai skills are one of the language skills that are felt to be quite difficult, this is evident from how low the average test result of the chookai examination of the Japanese Departments students in Japanese Language Proficiency Test. or commonly called Nouryokushiken in the past year. The Difficulties in listening to the conversation in Japanese, of course, were also experienced by the second level students of the Japanese Dearptment as foreign learners who were studying Japanese. For this reason, it is necessary to analyze and solve problems in chookai learning to increase the ability of students to listening skills using by action research. This study was aimed to describe the problems faced by students in learning Chookai and how the efforts of lecturer to overcome the problems. 


\section{METHOD}

The method used is descriptive analysis method with the instrument of research in the form of questionnaire to students and documentation studies to know the prbolems in learning of chookai faced by students, the factors that cause the problem, and the effort of students to overcome the problems. The Respondents in this study are 32 students of 2nd grade academic year 2017/2018 of Japanese Department at Universitas Komputer Indonesia

\section{RESULT AND DISCUSSION}

Based on the questionnaire distributed to students through the Google Form, it is known that the student's response to the Chookai course is presented in the following table 1:

TABLE I. STUDENT RESPONSES ABOUT CHOOKAI

\begin{tabular}{|c|c|c|c|c|c|}
\hline & & $\begin{array}{c}\text { Frequenc } \\
\mathbf{y}\end{array}$ & Percent & $\begin{array}{c}\text { Valid } \\
\text { Percent }\end{array}$ & $\begin{array}{c}\text { Cumulative } \\
\text { Percent }\end{array}$ \\
\hline \multirow[t]{5}{*}{ Valid } & 1 & 4 & 12.5 & 12.5 & 12.5 \\
\hline & 2 & 15 & 46.9 & 46.9 & 59.4 \\
\hline & 4 & 11 & 34.4 & 34.4 & 93.8 \\
\hline & 5 & 2 & 6.3 & 6.3 & 100.0 \\
\hline & Total & 32 & 100.0 & 100.0 & \\
\hline
\end{tabular}

From the table 1, it can be described that $12.5 \%$ of students strongly disagree, $46.9 \%$ disagree, $34.4 \%$ agree and $6.3 \%$ strongly agree that they have no difficulty in attending chookai lectures. So it can be concluded that more than half of 59.4 students have difficulty in attending chookai course. This is in line with Flores's opinion which states that listening comprehension is a difficult thing, because in the listening process related to the message delivered, the speaker, the listener, the speaker, the listener, and the physical setting [10]. Furthermore, Hirai explained that most students have difficulties in listening comprehenshion when learning foreign languages. [11]

The difficulties faced by students in attending chookai lectures are divided into seven parts including: difficulty in understanding vocabulary, difficulty in understanding sentence patterns, difficulty understanding the contents of short conversations, difficulty understanding the contents of long conversations. The difficulty of students in understanding the new Japanese vocabulary is presented in table 2:

TABLE II. DIFFICULTY UNDERSTANDING VOCABULARY

\begin{tabular}{|c|c|c|c|c|c|}
\hline & & $\begin{array}{c}\text { Freque } \\
\text { ncy }\end{array}$ & Percent & $\begin{array}{c}\text { Valid } \\
\text { Percent }\end{array}$ & $\begin{array}{c}\text { Cumulative } \\
\text { Percent }\end{array}$ \\
\hline \multirow{5}{*}{ Valid } & 1 & 2 & 6.3 & 6.3 & 6.3 \\
\hline & 2 & 13 & 40.6 & 40.6 & 46.9 \\
\hline & 4 & 15 & 46.9 & 46.9 & 93.8 \\
\hline & 5 & 2 & 6.3 & 6.3 & 100.0 \\
\hline & Total & 32 & 100.0 & 100.0 & \\
\hline
\end{tabular}

From the data above it can be described that $6.3 \%$ of students strongly disagree, $40.6 \%$ disagree, $46.9 \%$ agree and $6.3 \%$ strongly agree that they have no difficulty in mastering vocabulary. So that it can be concluded that almost half of $46.9 \%$ of students have difficulty understanding Japanese vocabulary well.

The difficulty of students in understanding the new Japanese sentence patterns is presented in the following table 3:

TABLE III. DIFFICULTY UNDERSTANDING SENTENCES PATTERNS

\begin{tabular}{|c|c|c|c|c|}
\hline & $\begin{array}{c}\text { Frequenc } \\
\mathbf{y}\end{array}$ & Percent & Valid Percent & $\begin{array}{c}\text { Cumulative } \\
\text { Percent }\end{array}$ \\
Valid 2 & 11 & 34.4 & 34.4 & 34.4 \\
4 & 18 & 56.3 & 56.3 & 90.6 \\
5 & 3 & 9.4 & 9.4 & 100.0 \\
Total & 32 & 100.0 & 100.0 & \\
\hline
\end{tabular}

From the table 3 , it can be described $34.4 \%$ of students disagree, $56.3 \%$ agree, and $9.4 \%$ strongly agree that they have difficulty understanding the sentence pattern properly. So it can be concluded that more than half that is $65.7 \%$ of students experience difficulties in understanding Japanese sentence patterns well.

Furthermore, students' difficulties in understanding short conversation content in Japanese are presented in table 4 below:

TABLE IV. DIFFICULTY UNDERSTANDING THE CONTENTS OF A SHORT CONVERSATION

\begin{tabular}{|c|c|c|c|c|c|}
\hline Valid & 2 & $\begin{array}{c}\text { Frequenc } \\
\mathbf{y} \\
2\end{array}$ & $\begin{array}{c}\text { Percent } \\
6.3\end{array}$ & $\begin{array}{c}\text { Valid Percent } \\
6.3\end{array}$ & $\begin{array}{c}\text { Cumulative } \\
\text { Percent } \\
6.3\end{array}$ \\
\hline & 4 & 25 & 78.1 & 78.1 & 84.4 \\
\hline & 5 & 5 & 15.6 & 15.6 & 100.0 \\
\hline & Total & 32 & 100.0 & 100.0 & \\
\hline
\end{tabular}

From the table 4 , it can be described that $6.3 \%$ of students disagree, $78.1 \%$ agree, $15.6 \%$ strongly agree that they have no difficulty in understanding short conversations. So it can be concluded that very few $6.3 \%$ of students have difficulty understanding the short conversations in Japanese well.

The difficulty of students in understanding long conversation content in Japanese is presented in the following table 5:

TABLE V. DIFFICULTY UNDERSTANDING THE CONTENT OF LONG CONVERSATIONS

\begin{tabular}{|c|c|c|c|c|}
\hline & $\begin{array}{c}\text { Frequenc } \\
\mathbf{y}\end{array}$ & Percent & Valid Percent & $\begin{array}{c}\text { Cumulative } \\
\text { Percent }\end{array}$ \\
\hline Valid & 1 & 3.1 & 3.1 & 3.1 \\
\hline
\end{tabular}




\begin{tabular}{l|c|c|c|c|}
\hline 2 & 16 & 50.0 & 50.0 & 53.1 \\
4 & 12 & 37.5 & 37.5 & 90.6 \\
5 & 3 & 9.4 & 9.4 & 100.0 \\
Total & 32 & 100.0 & 100.0 & \\
\hline
\end{tabular}

From the table 5, it can be described that $3.1 \%$ of students strongly disagree, $50 \%$ disagree, $37.5 \%$ agree and $9.4 \%$ strongly agree that they have no difficulty understanding the difficulties of tackling the contents of a long conversation. So it can be concluded that more than half that is $53.1 \%$ of students have difficulty understanding the contents of long conversations in Japanese well.

Based on tables 2, 3, 4, and 5 above, it is known that the difficulties faced by students are; 1) vocabulary mastery, 2) grammar mastery, 3) understanding of short and long conversation contents. This is understandable because of the cultural differences and sentence structure between Indonesian and Japanese which can make students confused. This is in accordance with Flores's opinion which states that the difficulties faced by students are limitations in vocabulary mastery, and also limitations in lexical and grammatical knowledge [10]. Furthermore, Takanashi explained that the difficulties faced by students in learning foreign languages due to pedagogical and cultural factors [12].

Furthermore, the factors that cause these difficulties are presented in table 6 :

\section{TABLE VI. CAUSES OF DIFFICULTIES}

\begin{tabular}{|l|l|}
\hline 1 & Internal factors \\
\hline & $\begin{array}{l}\text { a. } \quad \text { Limited vocabulary mastery owned by respondents. } \\
\text { b. Not confident. } \\
\text { c. } \quad \text { Lack of interest and learning motivation can be seen from } \\
\text { the lack of seriousness of respondents in doing the tasks } \\
\text { given. } \\
\text { d. Responses rarely practice and repeat lessons taught in the } \\
\text { classroom. }\end{array}$ \\
$\begin{array}{l}\text { External factors } \\
\text { a. Respondents felt that the time allocation for the subjects } \\
\text { was felt to be lacking } \\
\text { b. Respondents felt that the material taught was too much } \\
\text { and difficult } \\
\text { c. Some respondents felt that they were not in accordance } \\
\text { with the chookai teaching method conducted by the } \\
\text { lecturer }\end{array}$ \\
\hline
\end{tabular}

Based on the table 6 , it can be seen that one of the causes of difficulties faced by students in listening to Japanese is due to teaching factors. Therefore, in accordance with the opinion of Cutrone that teachers should be able to create a comfortable learning atmosphere so that they can motivate students to be more active in learning [13]. Furthermore, Hasan explained that in order to overcome student difficulties in the learning of listening comprehenshion, the teacher's creativity is needed to use various effective techniques and strategies, so that students have high motivation in learning listening. [14] In addition, Nachoua suggested the use of CALL (Computer-Assisted
Language Learning) as an effective method to increase student motivation so that students' ability in listening comprehension could be better [15]. The other efforts that should be done by the teacher to improve listening ability are expressed by Herron and Seay by adjusting the speed and content level of the conversation [16]

The efforts made by students to overcome these difficulties are as follows:

1. When experiencing difficulties in Chookai lectures in class, students ask friends and lecturers.

2. To broaden students' vocabulary, they often listen to songs, watch films or dorama, and read Japanese comics.

3. Often communicate using Japanese with friends, lecturers and Japanese people to improve listening skills.

4. Be more active and earnest in learning, either independently or in groups.

The efforts made by these students, in line with Idrissova, Smagulova and Tussupbekova's opinion which states that creative and varied activities carried out by students in learning foreign languages can motivate students to learn foreign languages more diligently, so that it will improve the students' language knowledge. [17].

\section{CONCLUSIONS}

Based on the five problems faced by the students mentioned above, it appears that the difficulty in understanding long conversation content is the most difficult problem faced by students. This is understandable because long conversation is an accumulation of understanding of vocabulary, sentence patterns, and short conversations. Therefore, teachers should provide better motivation for students to be more serious and study hard so that their listening skills increase.

\section{ACKNOWLEDGMENT}

We acknowledge that the partial financial support of this research is from The Directorate of Research and Community Services (LPPM) of Universitas Komputer Indonesia.

\section{REFERENCES}

[1] Sudjianto. Metode Pengajaran Menyimak. Direktori File Universitas Pendidikan Indonesia, Bandung 2012.

[2] L. Cameron. Teaching Languages to Young Learners. Cambridge: Cambridge University Press. 2001

[3] H.G. Tarigan, Menyimak Sebagai Suatu Keterampilan Berbahasa. Bandung: Angkasa, 1986T.

[4] Wallace, W. E. Stariha and H. J. Walberg. Teaching Speaking, Listening, and Writing. an International Academy of Education (IAE) Journal. UNESCO International Bureau of Education. 2004

[5] F. Yagang. Listening: Problems and Solutions. English Teaching Forum, Vol.31 (2), 16-19. Office of English Language Programs. Bureau of Educational and Cultural Affairs 1993. 
[6] L. Shi. Textual Borrowing In Second-Language Writing. Journal Written Communication Volume: 21 Issue: 2, Page(S): 171-200. 2004

[7] L. Miller. Developing Listening Skills with Authentic Materials. ELC 689: English as a Foreign Language (EFL) Assessment Continuing and Professional Studies, UMBC. USA. Maryland. 2003

[8] E. Wagner \& P.D . Toth. Teaching and Testing L2 Spanish Listening Using Scripted vs. Unscripted Texts. Journal Foreign Language Annals

Volume 47, Issue 32014 Pages 404-422. 2014

[9] M. A. Bingol, B. Celik, N. Yildiz, C. Tugrul mart. Listening Comprehension Difficulties Encountered by Students in Second Language Learning Class. Journal of Educational And Instructional Studies In The World November 2014, volume: 4 issue: 4 contents issn: $2146-7463$ pp.1-6 2014

[10] B.M. Flores. Learners' Awareness of Listening Comprehension A percepção dos alunos da compreensã da escuta. Textura. Canaos. N6/7. P.99-106. 2002

[11] A. Hirai. The Relationship between Listening and Reading Rates of Japanese EFL Learners. The Modern Language Journal Volume83, Issue3 September 1999 Pages 367-384

[12] Y. Takanashi. TEFL and Communication Styles in Japanese Culture. Journal Language, Culture and Curriculum Volume 17, 2004 - Issue 1 Pages 1-14

[16] C. A. Herron and I. Seay. The Effect of Authentic Oral Texts on Student Listening Comprehension in the Foreign Language Classroom. Journal Foreign Language Annals Volume 24, Issue 6 December 1991 Pages 487-495.

[17] M. Idrissova, B. Smagulova, and M. Tussupbekova. Improving listening and speaking skills in mixed level groups (on the material of New English File). Procedia - Social and Behavioral Sciences 199 ( 2015 ) Pages $276-284$
[13] P. Cutrone. Helping Japanese ESL/EFL Learners Overcome Difficulties in Intercultural Communication. Journal of the Faculty of Global Communication, University of Nagasaki. No. 11. 2010

[14] A.S. Hasan. Learners' Perceptions of Listening Comprehension Problems. Journal Language, Culture and Curriculum Volume 13, 2000 - Issue 2 Pages 137-153. 2000

[15] H. Nachoua. Computer-Assisted Language Learning for Improving Students' Listening Skill. Procedia - Social and Behavioral Sciences Volume 69, 24 December 2012, Pages 1150-1159.2012 